\section{Centenary of the Geological Survey of India}

The Geological Survey of India, one of the oldest official organizations of its kind in the world, is due to celebrate in January 1951 the first hundred years of its existence as an organized department. In 1846 the East India Co., on the advice of Sir Henry De la Beche, director-general of the Geological Survey of Great Britain, and of Sir Roderick Murchison, president of the Geological Society of London, appointed D. H. Williams "to investigate the Coal districts of India". After Williams's death in $\mathbf{1 8 4 8}$ there was a partial break in the work, but in 1851, when Thomas Oldham was appointed "Geological Surveyor to the East India Company", the uninterrupted history of the Survey may be said to have begun. To commemorate the occasion, the Government of India has arranged a number of events in which representatives of geological surveys and learned societies have been invited to participate. The main celebrations will be held in Calcutta during January 10-14, and these will include an exhibition illustrating the history of the Department and the progress of geological discovery in India, and a commemoration ceremony on January 13. This will be followed by a tour to places of geological and mining interest in northern India, concluding at Delhi on January 28. Prior to this, however, the thirty-eighth annual session of the Indian Science Congress, and the first meeting of the Pan Indian Ocean Science Congress (attended by delegates from most of the countries of Gondwanaland), will be held simultaneously in Bangalore during January 2-8, and a number of geologists are expected to attend the Section of Geology and Geography. Further particulars with regard to the centenary celebration programme can be obtained from the Director, Geological Survey of India, 27 Chowringhee, Calcutta 13.

\section{Forest Economy of Private Estates}

IN the Institute Paper No. 25 under the heading, "The Forest Economy of Three Private Estates in Great Britain", Mr. J. J. MacGregor, of the Department of Forestry, University of Oxford (I. F. Institute, University of Oxford, 1949), contrasts the forest economy and management of three differing private estates of which the records of their woods were detailed and covered a sufficiently long period of years to render a comparison possible. The usual trouble about private estates in the past has been that though the finances of the agricultural part of the estate as also of the shootings were accurately kept from year to year, little information about the true finance of the woods was available, being often only represented by the total sum obtained when the wood was clear felled. As the writer says, "Without further considerable effort it is difficult to co-ordinate odd scraps of financial information about, say, the costs of planting, and about sales of pitwood with the ultimate function of the woodlands on the private estates where they are situated. The physical features, the scale and intensity of operations, the capital structure and the extent and variety of the various types of income, the ratio of woodland to agricultural area, and proximity to markets, are all considerations which make one private estate differ economically from another, and also greatly influence the functions of woodlands in the general economy of the estate." A general study of the history of the past appears to show "that since about 1880 estates showed a declining income from farm rents, an increase in taxation burdens and an increase in the cost of upkeep. Although rents might have increased slightly in the period of the First World War, this was more than offset by the increases in the two main expenditure items. It is less easy to generalize about the course of income from the woodlands and about other factors." In this brochure Mr. MacGregor has produced information which should prove of value to all private estate owners.

\section{Characteristics and Uses of a Mechano-electric Transducer}

SINCE its introduction to Great Britain in late 1948, the $R C A-5734$ mechano-electronic transducer has proved itself to be a valuable and versatile research tool. It is a triode-transducer intended to provide a method of translating mechanical into electrical current variations which can be observed and measured. The triode has a metal envelope which forms the anode of the valve, and consists of a plate connexion with a thin metal diaphragm at the top, through the centre of which the plate sheft extends. Displacement of the plate shaft changes the distance of the fixed grid from the plate and results in a change of plate current. The deflexion sensitivity is 40 volts per degree deflexion of the plate shaft, but the safe limit of deflexion from the normal position is half a degree. The part of the plate shaft within the valve has a minimum free cantilever resonance of $12,000 \mathrm{c.} / \mathrm{s}$., permitting, with suitable mechanical coupling to the external end of the plate shaft, measurements of vibration up to that frequency. The moving element is designed to have very low inertia. The transducer may be mounted in any position. It weighs $1.75 \mathrm{gm}$. and is cylindrical of height $1_{32}^{9}$ in. and diameter $\frac{5}{16}$ in.

The transducer has applications in many fields. The wide variety of uses to which it may be applied includes gust-recording anemometers for wind-velocity surveys; oscillograph recording, through a diaphragm attached to the plate shaft, of tank pressures set up during the short-circuit testing of eircuit breakers; the direct measurement of arterial and venous blood pressures and the record of pulsations in the arteries; pressure recording through a cardiac catheter in the interior of the human heart; and stress evaluation and vibration phenomena in the motor, aircraft and shipbuilding industries. Board of Trade authority for the importation of a small stock of transducers for the benefit of approved institutions has been granted, and colleges, medical schools and research organizations interested should apply to R.C.A. Photophone, Ltd., 36 Woodstock Grove, London, W.12.

\section{Fungicidal Action of Disodium Ethylene bisDithio- carbamate}

DisodiUm ethylene bisdithiocarbamate (DSE), first synthesized in 1935, gave a rather erratic performance as a fungicide in the field, until Heuberger and Manns found that its performance could be improved by the addition of zinc sulphate and lime. Raymond W. Barratt and James G. Horsfall (Conn. Agric. Exp. Sta. Bull. 508 ; pp. 51 ; New Haven, U.S.A. ; June 1947) conducted a laboratory investigation into the efficiency and mode of action of thirty-six anslogues and homologues of the compound, using spores of the fungus Stemphylium sarcinceforme for the tests. It was concluded, in general, that dithiocarbamate analogues inhibit spores through two reactions: by liberating sulphuretted hydrogen, and by forming metal salts of the compound. Fungi- 